\title{
FDI sway on economic growth: a case study of China
}

\author{
Farrukh Shahzad $^{1 *}$, Ahsan Zia ${ }^{1}$, Bushra Zulfiqar ${ }^{2}$, Zeeshan Fareed ${ }^{3}$ \\ ${ }^{I}$ Department of Management Sciences, Lahore Leads University, Lahore, Pakistan \\ ${ }^{2}$ University of the Punjab, Lahore, Pakistan \\ ${ }^{3}$ Department of Management Sciences, COMSATS Institute of Information Technology Sahiwal, Pakistan \\ *Corresponding author E-mail: farrukh.hailian@gmail.com
}

\begin{abstract}
This research paper intends to examine the effect of outside Foreign Direct Investment (FDI) in China for the period 1987 to 2013. It assessed the GDP development execution and evaluated the historical tend of the FDI and CPI in China. The connection between gross domestic product (GDP,) foreign direct investment and Inflation is measured with the assistance of various relapse models. We used Tstatistics and multiple regressions on data. GDP in this model is utilized as dependent variable though FDI and swelling (CPI) are measured as independent variables. As indicated by the results, the model is general reveal that there is positive and significant relationship of GDP with FDI and also positive and significant relationship found between GDP and CPI. On the premise of the experimental results gained, policy maker should play a vital role to invest FDI may be included in the exchange of assets from less beneficial to more gainful divisions of the economy.
\end{abstract}

Keywords: Foreign Direct Investment, Consumer Price Index, Gross Domestic Product, China.

\section{Introduction}

China accustomed a standout amongst the most shut economies as far as approach to foreign direct investment and outer obligation. Beginning from practically no outside possessed firms on Chinese soil before 1979, China has turned into one of the biggest forming host nations for foreign investment with the stream of foreign direct investment (FDI) arriving at \$26 billion (U.S) in 1993 (China State Statistics Department 1994). This emotional change is some piece of the general Chinese exertion that started around 15 years back to change the monetary framework and exposed to the outer world (Wei, 1996). Now the Chinese terrain enrolled 127 billion US dollars of Foreign Direct Investment (FDI) inflows in 2013, end the crevice with the United States to around 32 billion dollars, as per the United Nations Conference on Trade and Development (UNCTAD).

This paper has two targets. Initially, it looks to analyse FDI in China from a global viewpoint. Specifically, it asks whether China has gotten "enough" FDI from real source nations in the wake of controlling for key monetary attributes. Second, the paper examines a few results of FDI in China, especially FDI's commitment to China's quick development, its fares, and its change exertion. In addition it will also elaborate the relationship between FDI, GDP and CPI in china's economic growth.

The study indicates china's experience with FDI and distinguishes a few lessons for different nations. The greater part of the components clarifying china's prosperity has likewise been paramount in drawing in FDI to Other nations: Market size, work costs, nature of framework and government approaches. FDI has contributed to higher financing and gainfulness development, and has made employments and element expert division. China's success nonetheless, did not come without a few pitfalls: an increasingly intricate expense motivating force framework and browning territorial Wage aberrations. Promotion to the WTO should grow China's "opening up" approaches and continue FDI's commitments to china's economy later on (Zebregs \& Tseng, 2002)

In the wake of receiving the open door policy, China accomplished a blast of foreign direct investment (FDI) by multinational enterprises since 1980s. In the first period 1979-1983, FDI inflows into China were with constrained sum. In the 1982, the inflow FDI to China was 430 million of US dollars. 1983 the inflow go to 636 million of US dollars. The normal yearly inflow is 533 million.

Table1: The Average Annual Inflow in Three Periods (Million US \$)

\begin{tabular}{ll}
\hline 4 Periods & Average annual FDI Inflow \\
\hline $1982-1983$ & 533 \\
$1984-1991$ & 2693.25 \\
$1992-2006$ & 50881.62445 \\
$2007-2013$ & 253044.7143 \\
\hline
\end{tabular}

Source: World Bank (World Development Indicator)

From 1984, the inflow of FDI began to take off steadily from the yearly inflow of 1,258 million US dollar (1984) to 4366 million (1991). The yearly development rate from 1985 to 1990 keep positive with the reach from $3 \%$ to $38 \%$. The average yearly inflow is 2,693 million US dollar.

Since 1992, the inflows of FDI into China quicken. The yearly inflow began from 11,156 (1992) million of US dollar to 87,286 million (2006). The yearly development rate keep positive amid the third period with the exception of the rate in 1999 was $10.14 \%$. Besides the rate in $1998(0.45 \%)$ and 2000 (2.63\%) was slight positive. This transitory deferral may because of the impact from Asian budgetary emergency. In any case, from 2001, the inflow of FDI to China has recuperated from the emergency with the yearly development rate of $11.77 \%$ and arrived at another record of 47,052 million US dollar. In 2005, there is speeding up in the inflow FDI with the $41.32 \%$ development rate and drop to 
86,071 million US dollar. The average yearly inflow in this period was 50881.62445 US dollar.

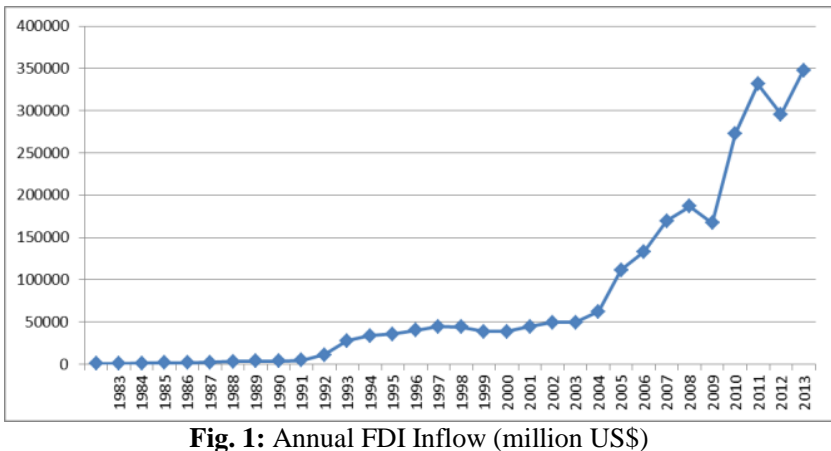

Source: World Bank (World Development Indicator).

From a practically separated economy, China turned to be the biggest beneficiary of FDI in the creating scene. The FDI inflow to terrain China in 2006 was 69.47 billion US dollars, which was $18 \%$ of the creating nations and $5.32 \%$ of the world. The amassed FDI inflows to China until 2006 arrived at 293 billion US dollar, constituting in excess of $9.27 \%$ of aggregate FDI into all creating nations, $2.44 \%$ of the world aggregate FDI stocks (UNCTAD 2007). Since 2007, the inflows of FDI into China stimulate again and started dramatically changed from the amount 169390 (2007) millions of dollars to 347849 (2013) millions US dollars.

The previous examination papers concerning on determinants FDI inflow to China help the advancement of FDI to the high developing GDP and the tremendous populace, which supplies an immense business sector, as well as the exhaustless and shabby works for the creation too. Nonetheless, truly, there are more financial components can consider for the expanding the FDI inflows into China, for example, duties, trade rates, base advancements and so forth, from the exact side, there are more models connected into Chinese information of these variables.

\subsection{Financial year-wise inflows of foreign direct invest- ment in China}

\begin{tabular}{|c|c|c|c|c|c|}
\hline \multirow[t]{2}{*}{$\frac{\text { Financial Year }}{\text { (April-March) }}$} & \multicolumn{2}{|c|}{$\frac{\text { FDl equity inflows }}{\text { From China }}$} & \multicolumn{2}{|c|}{$\frac{\text { FDI equity inflows from all }}{\text { Countries * }}$} & \multirow{2}{*}{$\begin{array}{c}\frac{\text { Total FDI }}{\text { inflows }} \\
\text { (including } \\
\text { equity, } \\
\text { re-invested } \\
\text { earnings \& } \\
\text { other capital) ** } \\
\text { (US\$ in million) }\end{array}$} \\
\hline & Rs. in crores & $\begin{array}{l}\text { USS in } \\
\text { million }\end{array}$ & $\begin{array}{l}\text { Rs. in } \\
\text { crores }\end{array}$ & $\begin{array}{l}\text { USS in } \\
\text { million }\end{array}$ & \\
\hline $2000-01$ & 0.00 & 0.00 & 10,733 & 2,463 & 4,029 \\
\hline $2001-02$ & 0.00 & 0.00 & 18,654 & 4,065 & 6,130 \\
\hline 2002-03 & 0.25 & 0.05 & 12,871 & 2,705 & 5,035 \\
\hline 2003-04 & 0.26 & 0.06 & 10,064 & 2,188 & 4,322 \\
\hline 2004-05 & 5.98 & 1.35 & 14,653 & 3,219 & 6,051 \\
\hline 2005-06 & 4.17 & 0.91 & 24.584 & 5,540 & 8,961 \\
\hline 2006-07 & 3.14 & 0.68 & 56,390 & 12,492 & 22,826 \\
\hline $2007-08$ & 4.38 & 1.09 & 98,642 & 24,575 & 34,843 \\
\hline 2008-09 & 32.38 & 6.71 & 142,829 & 31,396 & 41,873 \\
\hline 2009-10 & 199.99 & 41.36 & 123,120 & 25,834 & 37,745 \\
\hline $2010-11$ & 7.03 & 1.56 & 97,320 & 21,383 & 34,847 \\
\hline $2011-12^{\wedge}$ & 358.38 & 72.69 & 165,146 & 35,121 & 46,556 \\
\hline $2012-13$ & 812.51 & 151.86 & 121,907 & 22,423 & 36,860 \\
\hline $\begin{array}{l}2013-14 \text { (up to } \\
\text { February, 2014) }\end{array}$ & 729.36 & 117.81 & 125,960 & 20,766 & 31,731 \\
\hline $\begin{array}{l}\text { Cumulative Total } \\
\text { (April 2000-February } \\
\text { 2014) }\end{array}$ & $2,157.84$ & 396.13 & $1,022,873$ & 214,170 & 321,809 \\
\hline
\end{tabular}

Fig. 2: Amount Of FDI Inflows 2001-2014

Source: Reserve bank of India, 2014

Note:

i. *These amounts include the inflows received through FIPB/SIA route, acquisition of existing shares, RBI's automatic route and RBI's - NRI schemes.

ii. The amount of FDI equity inflows, in respect of country/sector specific data was not provided by RBI, Mumbai, prior to April 2000.

iii. ^Inflows for the month of March, '12 are as reported by RBI, consequent to the adjustment made in the figures of March, '11, August, ' 11 and October, '11. iv. **Country \& sector specific details on 're-invested earnings' and 'other capital' are, however, not centrally maintained by the Reserve Bank of India.

v. **Data in respect of 'Re-invested earnings' \& 'Other capital' for the years 2009-10, 2010-11, 2011-12, 2012-13 \& 2013-14 are on an estimated basis. It is estimated by RBI as an average of the previous two years.

\subsection{Universal structures of foreign direct investment in China}

Before 1979, practically no outside claimed firms did work in China, nor did China have numerous outer advances. Chinese pioneers used to take pride in this. In fact, even remote help volunteered by outside governments or universal associations was seen with suspicion. For instance, after the incredible 1976 seismic tremor in Tangshang (which enlisted around 8 on the Richter scale and brought on a huge number of passing), the Chinese government rejected a help offer from the International Red Cross. This demeanour to remote cash took a sensational turn in 1979 when Deng Xiaoping presented monetary change and started the "open door policy."

Numerous factors helped this change. Two essential ones are (1) the unfortunate financial execution under unbending focal arranging before 1979 and (2) the sparkling cases of Japan and the four Asian "tigers," especially Hong Kong and Taiwan.

\subsection{FDI inflows in China by geographical distribution}

Dispersion example of FDI inflows in China demonstrates the extraordinary difference among districts due to the inclined particular arrangements driving FDI inflows in the eastern open regions and SEZs amid the early open way to the world. This has brought about a mind-boggling convergence of FDI inflows in the eastern area. However, after Deng's discourse in the southern visit, China's legislature has quickened the pace of monetary change to actualize the all the more comprehensively open entryway approaches over all the areas for FDI inflows. In this way, FDI inflows into China have begun to spread to across the country regions from waterfront zones to inland territories. With a specific end goal to catch the entire picture of the uneven appropriation of FDI inflows in China, all the areas of China might be partitioned into the three unique districts by the distinctive land areas, for example, eastern district, centre area, and western locale (Jiang, 2003).

\section{Literature review}

During the most recent decade various fascinating studies have been taking on Foreign direct investment in invigorating monetary development has showed up. A review by OECD (2002) underpins these perceptions and reports that 11 out of 14 studies have discovered FDI to help emphatically to wage development and element gainfulness. Both de Mello and OECD stress on key knowledge from all studies surveyed: the path in which FDI influences development is liable to rely on upon the monetary and innovative conditions in the host nation.

Four studies, depending on a mixture of cross-country relapses, have researched the vital conditions for recognizing a positive effect of FDI on financial development. Interestingly, they stretch distinctive, however nearly related, parts of improvement. In the first place, Adeniyi, Omisakin, \& Oyinlola,( 2012) contend that FDI has a positive development impact when a nation is sufficiently rich regarding for every capita salary. Second, Ilhan, (2007) accentuate exchange openness as being significant for getting the potential development effect of FDI. Third, E Borensztein, (1998) find that FDI raises development, however just in nations where the work power has accomplished a certain level of instruction. At last, Laura Alfaro, (2009) attract consideration regarding monetary markets as they find that FDI pushes financial development in 
economies with sufficiently created budgetary markets. Notwithstanding, when Carkovic and Levine (2002) appraisal the impacts of FDI on development in the wake of controlling for the potential inclinations affected by endogeneity, nation particular impacts, and the exclusion of beginning pay as a regressor, they discover, utilizing this changed detail that the consequences of these four papers break down. Carkovic and Levine reason that FDI has no effect on long run development.

The observational proof on whether global capital portability, by means of FDI or different structures, helps development, notwithstanding, is blended. Looking over the writing, Kose, (2006) infer that the macroeconomic writing does not appear to discover a powerful noteworthy impact of budgetary incorporation on monetary development. Notwithstanding, this writing has observed that establishments, particularly fiscal improvement (limit impacts or all the more by and large the 'absorptive limits'), assume a paramount part. In this civil argument, FDI can assume an essential part. That is, money related opening and the ensuing inflows of FDI could prompt a build in TFP through information overflows, engineering exchanges and the encouraging of linkages with residential firms, contingent upon the nearby conditions.

A paramount study by (Abbas, 2011) led an examination on the impact of FDI and CPI on the GDP's of SAARC part countries. The study finished up that the general model in these nations created a positive relationship between Foreign Direct Investment and GDP while negative relationship between Consumer Price Index furthermore GDP. This conclusion was tried utilizing the different relapse models. The information of the SAARC nations extended from the year 2001 to 2010 . Wu, (2008) attempted to discover if FDI can encourage monetary improvement. The study connected the limit relapse investigation. The observational dissection presumed that FDI does assume a characterizing part in the monetary improvement. This was discovered after an examination of information of 62 nations from the year 1975 to 2000. The study found that FDI depends fundamentally on the starting GDP and human capital. This implies that nations that have a huge GDP and human before FDI demonstrated a positive relationship. Alfaro et al (2004) additionally completed a comparative examination of the relationship of FDI and GDP development. The study additionally demonstrated that nations with a solid fiscal framework are more fit for misusing the capability of FDI. Through experimental dissection of the information somewhere around 1975 and 1995, it was observed that FDI had a more prominent effect in nations with a stable monetary framework.

\section{Methodology of research}

The motivation behind this research paper is to analyse the connection of China's GDP with FDI and Inflation (CPI). Study covered the time period from 1980-2013. World Bank is measured as a bona fide wellspring of information accumulation thusly; optional information of the said variables is gathered from this dependable source. To analyse the connection of China's GDP with FDI and Inflation (CPI), the accompanying hypothetical model is utilized.

\section{GDP $=\mathbf{f}($ FDI \& CPI $)$}

The centre plan of the paper is to study the impact of FDI on GDP of China. The pattern of remote Direct Investment inflows is likewise seen with importance to GDP development and swelling of china. To look at the connection of China's GDP with FDI and swelling (CPI), the accompanying various relapse model is utilized,

$\boldsymbol{G D P}=\beta_{0}+\beta_{1} \boldsymbol{F D I}+\beta_{2} \boldsymbol{C P I}+\boldsymbol{\mu}$

Where,

FDI $=$ Foreign Direct Investment

GDP $=$ Gross Domestic Product

CPI = Inflation Rate

Level of Significant: 5 to 10 percent
The previously stated Multiple Regression Model was run on EViews to figure out the Impact of FDI and CPI on the Gross Domestic Product of Pakistan. In this different relapse model, GDP is utilized as indigent variable though FDI and CPI are measured as free variables. To gauge the impact of FDI on GDP of China, Multiple Relapse Model is connected over the time of 1981 to 2010. Two inputs are utilized; outside immediate financing and swelling. Clear detail of GDP, FDI and CPI are as takes after.

\subsection{Measures the output (GDP)}

We utilized GDP, as a yield development pointer in the Multiple Regression Model, tagged in comparison 1.data arrangement blankets the period from 1982 to 2013 and is taken from the World Bank. GDP is measured in million US Dollars. It is utilized as needy variable in the proposed model. The vertical axis (X-hub) is the year and flat hub (Y-hub) is GDP (percentage). Development of GDP in these specified thirty years is indicating the pattern of vacillations.

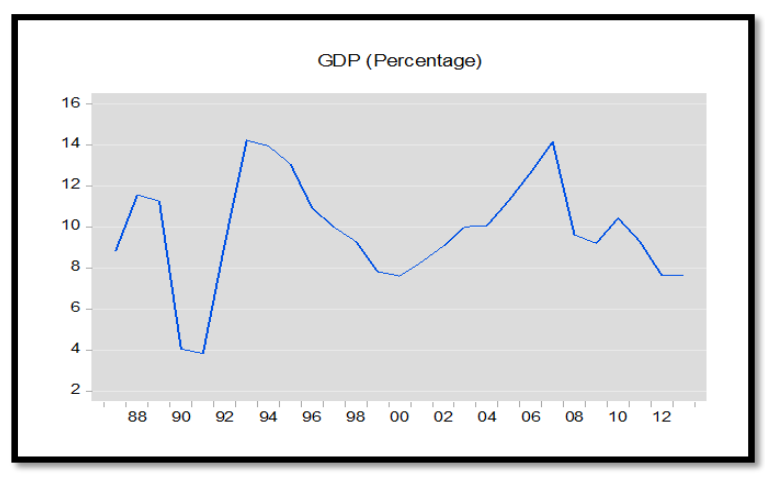

Fig. 3: GDP Annual Growth Rate

Source: World Bank (World Development Indicator)

\subsection{Measures the input (FDI)}

We utilized FDI, as an information development marker in the Multiple Regression Model, detailed in comparison 1. Information arrangement blankets the period from 1982 to 2013 and is taken from the World Bank. FDI is measured in million US Dollars. It is utilized as autonomous variable in the proposed model and discovered profoundly successful and noteworthy. The vertical hub (Xaxis) is the year and even hub (Y-hub) is FDI (in Million Us Dollars). FDI in these specified thirty years is demonstrating the pattern of changes.

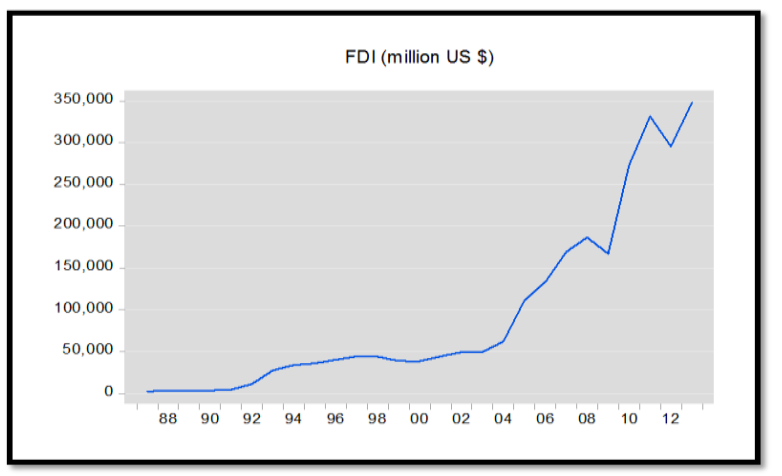

Fig. 4: Annual FDI

Source: World Bank (World Development Indicator)

\subsection{Measures of input (CPI)}

We utilized CPI, as an information development pointer in the Multiple Regression Model, indicated in mathematical statement 1.data arrangement blankets the period from 1981 to 2010 and is 
taken from the World Bank. FDI is measured in million US Dollars. It is utilized as free variable in the proposed model and discovered critical. The vertical pivot (X-hub) is the year and even pivot (Y-hub) is CPI (in rate). CPI in these said thirty years is demonstrating the pattern of vacillations.

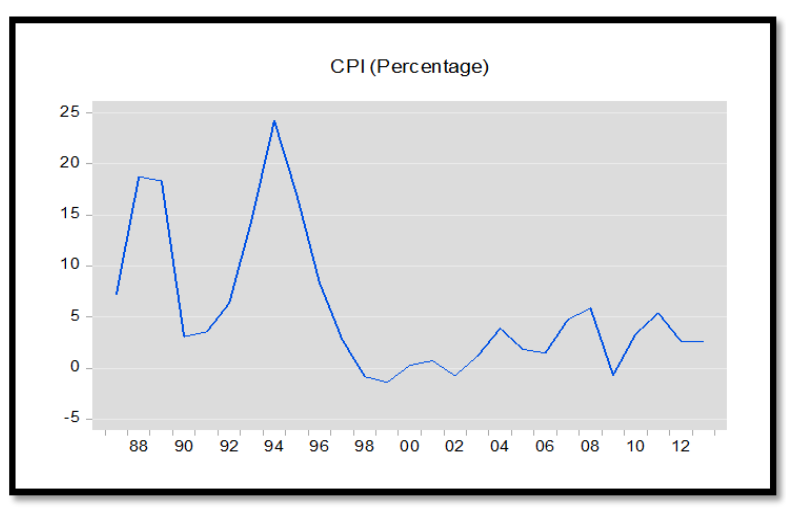

Fig. 5: Annual FDI

Source: World Bank (World Development Indicator)

\section{Empirical results}

\section{a) Unit root}

If the time series data is non-stationary then it can be create problem in empirical analysis. Non-stationary data leads to spurious results so, it is necessary to check the series whether it is stationary or non-stationary. ADF test is used to check the stationary of the data.

$\mathrm{H}_{0}=$ Series contains unit root

$\mathrm{H}_{1}=$ Series is stationary

Table 2: Unit Root Results

\begin{tabular}{|l|l|l|l|l|}
\hline \multirow{2}{*}{ Variables } & \multicolumn{2}{|l|}{ ADF test at level } & ADF test at 1st difference \\
\cline { 2 - 5 } & Calculated & lag & Calculated & lag \\
\hline GDP & 2.49 & 1 & $4.51^{* *}$ & 1 \\
\hline FDI & 2.30 & 1 & $4.45^{* *}$ & 1 \\
\hline CPI & 2.72 & 1 & $4.21^{*}$ & 1 \\
\hline
\end{tabular}

Note:*,** indicate the significance at $5 \%$ and $1 \%$ level respectively

Table 2 shows the unit root results with trend and intercept which indicates that all variables are non-stationary at level. So our null hypothesis that series contains unit root is accepted. However, the series has not unit root problem when the series at first difference. So our null hypothesis is rejected in this case. It means that series is stationary at first difference at $1 \%$ level of significant except CPI which is stationary at $5 \%$ level of significant.

\subsection{Research model}

The multiple regressions model used for the following study.

$\boldsymbol{G D P}=\beta_{0}+\beta_{1} F D I+\beta_{2} C P I+\mu$

Table 3: Regression Results

\begin{tabular}{|c|c|c|c|c|}
\hline \multirow{2}{*}{\multicolumn{5}{|c|}{\begin{tabular}{|l} 
Dependent Variable: GDP \\
Method: Least Squares
\end{tabular}}} \\
\hline & & \multicolumn{3}{|c|}{ Method: Least Squares } \\
\hline \multicolumn{5}{|c|}{ Date: 09/09/14 Time: 10:47 } \\
\hline \multicolumn{5}{|c|}{ Sample: 19872013} \\
\hline \multicolumn{5}{|c|}{ Included observations: 27} \\
\hline Variables & Coefficient & Std. Error & t-Statistic & Prob. \\
\hline $\mathrm{C}$ & -2.598951 & 3.775271 & -0.688414 & 0.4987 \\
\hline LFDI & 1.004604 & 0.335957 & 2.990273 & 0.0070 \\
\hline CPI & 0.282871 & 0.068027 & 4.158240 & 0.0004 \\
\hline \multicolumn{2}{|c|}{ R Square $=0.52$} & \multicolumn{3}{|c|}{ Mean dependent var $=9.826743$} \\
\hline \multicolumn{2}{|c|}{ Adjusted $\mathrm{R}^{2}=0.49$} & \multicolumn{3}{|c|}{ S.D. dependent var $=2.600025$} \\
\hline \multicolumn{2}{|c|}{ F-statistic $=13.323168$} & \multicolumn{3}{|c|}{ Sum squared resid $=83.28976$} \\
\hline \multicolumn{2}{|c|}{ Prob (F-statistic) $=0.000444$} & \multicolumn{3}{|c|}{ Durbin-Watson $=0.931531$} \\
\hline
\end{tabular}

The proposed model exact results are delineated by the above table. The slope coefficients of the inputs (FDI) in the OLC investigates have positive impact on GDP whereas the slope coefficients of the inputs (CPI) have also positive impact on GDP

The change of one percent (\%) in FDI bring about $100 \%$ change in GDP while CPI will bring about $28.29 \%$ changed by 1 percent change in GDP by consider other variable constant. Assessment (FDI and CPI) highly significant.

The adjusted $\mathrm{R}$ square is .49 which explains $49 \%$ variation in the dependent variable (GDP) accounted for by the explanatory variables FDI and CPI. The value of Durbin Watson is .93 which means that there is positive autocorrelation of residual.

\section{Conclusion}

Investment always plays a vital role in the economic growth, augmentation in assets and frame in a country to boost up the economy. In an economy, foreign direct investment is revealing of a positive tendency of investment with ultimately translates in increase in GDP and economic tumour of the country. It also has been proven if we further investigate the previous studies that conducted. All struggles made in this respect must keep into thoughtfulness the economic, political and social state affairs of the country. China is a leading economy growth and a heaven for FDI due to many positive aspects like advancement in energy sector and tax relaxation zone. For a country like China, to gain a top position in FDI inward overall world is to concentrate on infrastructure progress, human resource exercises, boosting local entrepreneurs, creation of a steady macroeconomic background and ensuring prospects that would be advantageous for investors and to achieve the top ranking in FDI rivalry.

\section{Recommendations of policy}

Finding of our results are probably to provide an opportunity to edifice some policy implications.

The OLC results confirmed that a rise in FDI has positive impact on growth rate of China. Henceforward the establishments should positively essence on maximum deployment of resources to increase Foreign Direct Investment in order to escalation GDP growth rate. It needs more encouraging Foreign Direct Investment eye-catching policies from the public sector to achieve the top position in world.

\section{Economic reformation}

Monetary transformation implies the exchange of assets from less profitable to more gainful parts of the economy. Genuine development of generation is specifically related with the powerful methodology of economy rebuilding from the less profitable to the more beneficial areas of the economy. FDI may be included in the exchange of assets from less beneficial to more gainful divisions of the economy. Economy like china just does some effort to gain the top in FDI inward.

\section{References}

[1] Abbas, Q. A. (2011). Impact of Foreign Direct Investment. Global Journal of Management and Business Research, 11(8).

[2] Adeniyi, O., Omisakin, O., \& Oyinlola, A. (2012). Foreign Direct Investment, Economic Grouwth and Financial Sector Development in Small Open Develompent countries. Economic analysis and policies, 42(1), 105-127. http://dx.doi.org/10.1016/S0313-5926 (12)50008-1.

[3] E. Borensztein, J. D.-W. (1998). How does foreign direct investment affect economic growth? Journal of International Economic, 45, 115135. http://dx.doi.org/10.1016/S0022-1996 (97)00033-0.

[4] Ilhan, O. (2007). FOREIGN DIRECT INVESTMENT - GROWTH NEXUS: A REVIEW OF THE RECENT LITERATURE. International Journal of Applied Econometrics and Quantitative studies, 4(2), 120. 
[5] Jiang, X. (2003). Geographical Distribution of Foreign Investment in China: Industrial Clusters. World Economy and China, 11(1), 15-24.

[6] Kose, A. M.-J. (2006). NBER Working Paper. Financial Globalization: A Reappraisal, 12(8484).

[7] Laura Alfaro, S. K.-O. (2009). FDI, Productivity and Financial Development. The World Economy, 111-135. http://dx.doi.org/10.1111/j.1467-9701.2009.01159.x.

[8] OECD. (2002). Foreign Direct Investment for Development; Maximizi Costs. Paris.

[9] Wei, S.-J. (1996). Foreign Direct Investment in China: Sources and Consequences. National Bureau of Economic research, 5, 77-105.

[10]Wu, J. \&. (2008). Does Foreign Direct Investment Promote Economic Growth. Economics Bulletin, 15(12).

[11]Zebregs, H., \& Tseng, W. (2002). Foreign direct investment in china: lessons for other countries. IMF policy discussion paper, 1-26. 